\title{
New gall midges (Diptera, Cecidomyiidae) associated with two species of Eugenia (Myrtaceae)
}

\author{
Valéria Cid Maia ${ }^{1}$, Pedro de Araújo Lima Constantino² \& Ricardo Ferreira Monteiro ${ }^{2}$
}

\begin{abstract}
${ }^{1}$ Departamento de Entomologia, Museu Nacional, Quinta da Boa Vista, São Cristóvão, 20940-040 Rio de Janeiro-RJ, Brasil. maiavcid@acd.ufrj.br ${ }^{2}$ Laboratório de Ecologia de Insetos, Departamento de Ecologia, Instituto de Biologia, CCS, Universidade Federal do Rio de Janeiro, 21941-590 Rio de Janeiro-RJ, Brasil.pconst@usa.net; monteiro@biologia.ufrj.br
\end{abstract}

\begin{abstract}
New gall midges (Diptera, Cecidomyiidae) associated with two species of Eugenia (Myrtaceae). Jorgenseniella eugeniae, gen. nov., sp. nov. and Dasineura marginalis, sp. nov. are described based on material obtained from leaf galls on Eugenia umbelliflora and E. rotundifolia (Myrtaceae). Illustrations of adults, immature stages and galls are given. Trotteria sp. (inquiline) and Lestodiplosis sp. (predator) are associated with the galling species. Ecological aspects of galls and gall midge species are also presented.
\end{abstract}

KEYWORDS. Dasineura; Eugenia; Lestodiplosis; Jorgenseniella; Trotteria.

RESUMO. Novos mosquitos de galhas (Diptera, Cecidomyiidae) associadas a duas espécies de Eugenia (Myrtaceae). Jorgenseniella eugeniae, gen. nov., sp. nov. e Dasineura marginalis, sp. nov. são descritos com base em material obtido de galhas foliares em Eugenia umbelliflora e E. rotundifolia (Myrtaceae). Ilustrações dos adultos, fases imaturas e galhas são fornecidas. Trotteria sp. (inquilino) e Lestodiplosis sp. (predador) estão associados com as espécies galhadoras. Aspectos ecológicos das galhas e das espécies de cecidógenos são também apresentados.

PALAVRAS-CHAVE. Dasineura; Eugenia; Lestodiplosis; Jorgenseniella; Trotteria.

Insect galls are very frequent and abundant in Brazilian sand coastal plain (restinga), where the gall midges (Diptera, Cecidomyiidae) represent the most diverse galling family and Myrtaceae the most attacked host plant family (Monteiro et al. 1994, 2004; Maia 2001a,b). Among the Myrtaceae, Eugenia Linnaeus (Myrtaceae) is one of the most rich plant genus in number of species as well as in individual abundance in this ecosystem (Araujo 2000). Furthermore, Eugenia comprises the high diversity of Cecidomyiidae galls (14 kinds of galls). Maia (1993, 1994, 2001a) described six species of gall midges associated with this genus in restingas, two of them on Eugenia rotundifolia Casar and two on E. umbelliflora Berg (this last plant species referred as E. multiflora Camb. in Maia 2001a).

In the present work, a new genus and two new species of gall midges are described-Jorgenseniella eugeniae, gen. nov., sp. nov. and Dasineura marginalis, sp. nov.. Biological aspects of gall, including distribution pattern in the leaf, site of pupation and period of occurrence are added.

Dasineura Rondani, 1840 is a cosmopolitan and catchall genus with hundreds of species described. According to Gagné (1994), this genus is traditionally defined by the folllowing characters: palpus with 4 segments; tarsal claws toothed; R5 shorter than wing length; gonocoxites partially bare; female eighth tergite longitudinally divided; ovipositor elongateprotrusible; female cerci fused; spatula clove-shaped; larva with six lateral papillae on each side of the spatula and eight terminal papillae.

There are 13 species of Dasineura described to Neotropical region (Gagné 1994; Maia 1993 a,b; 2001; Angelo \& Maia 1999), but many of them probably do not belong to this genus (Gagné 1994). Seven of them were described from Brazil.

Jorgenseniella new genus, is described here for a single species, Jorgenseniella engeniae. It appears to be most similar to Calmonia Tavares, 1917, a neotropical genus with only two known species, both of them associated with Ficus sp. (Moraceae).

\section{MATERIAL AND METHODS}

During 2002, once each season, twenty Eugenia umbelliflora and E. rotundifolia plants on each of the three different restinga's areas were inspected and all kinds of gall found on them were collected. In the Restinga de Barra de Maricá (Maricá, RJ) the galls were collected only on Eugenia rotundifolia, in Parque Nacional da Restinga de Jurubatiba (Macaé, RJ) they were collected only on Eugenia umbelliflora and in Restinga de Arraial do Cabo (Arraial do Cabo, RJ) the galls came from both plant species. In the laboratory, the sampled galls were placed in plastic bags in order to obtain the adult insects.

The specimens were first preserved in $70 \%$ alcohol and then mounted on slides following the methodology of Gagné (1994). The genera were identified using Gagné keys (1994). All specimens (including the types) were deposited in the Diptera collection of Museu Nacional, Rio de Janeiro (MNRJ).

The field work was done by P. A. L. Constantino and R. F. Monteiro and the descriptions of the new taxa by V. C. Maia. 

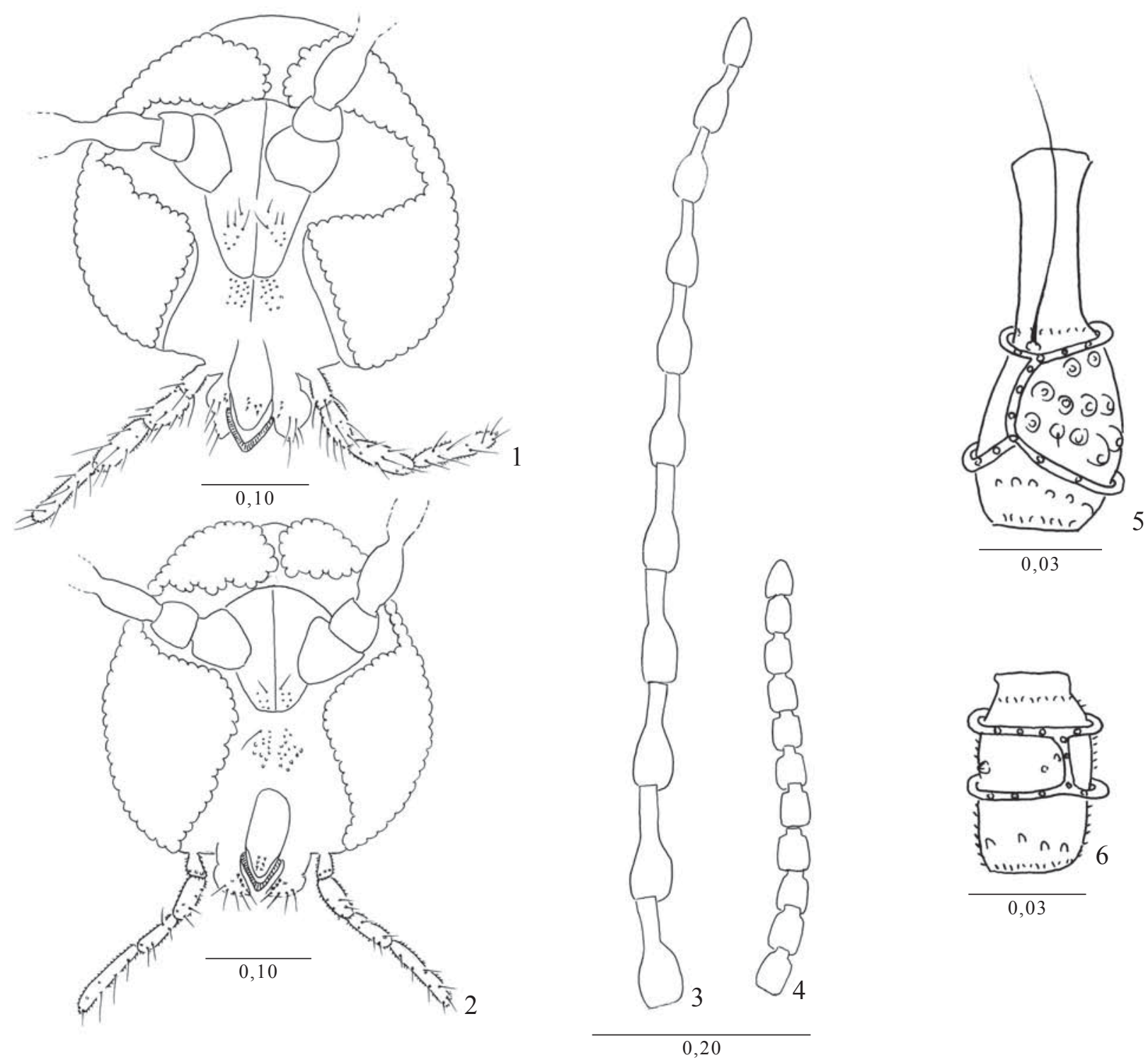

Figs. 1-6. Dasineura marginalis sp. nov.: 1, Male head, frontal view; 2, Female head, frontal view; 3, Male antenna; 4, Female antenna; 5, Flagellomere 5, male; 6, Flagellomere 5, female.

\section{Dasineura marginalis sp. nov.}

(Figs. 1-13)

Adult. Body length: 1.8-1.9 mm ( $\mathrm{n}=2$ males). Head (Figs. 12): Eyes facets hexagonal, closely approximated, except at the vertex and near antennal insertion. Antenna with 16-17 flagellomeres in male and 21-22 in female; scape triangular and setose; pedicel globose and setose; flagellomeres 1 and 2 connate; necks bare much longer in male than in female; basal flagellomeres longer than distal one in both sexes (Figs. 3-4). Circumfila as in Figures (5-6). Clypeus with many setae; labrum triangular, long-attenuate with three pairs of ventral sensory setae. Hypopharynx and labrum similar in shape and length; hypopharynx with long, anteriorly directed lateral setulae. Labellae elongate-convex, each with several lateral setae and three pairs of short mesal sensory. Palpus with four cylindrical and crescent segments, all setose.

Thorax: Anepimeron setose, other pleura bare. Wing length: $1.2-1.3 \mathrm{~mm}(\mathrm{n}=3)$; venation as in Figure 7. Tarsal claws toothed, empodium well developed (Fig. 8).

Abdomen. Male: tergites 2-6 rectangular with complete row of caudal setae, several lateral setae, two basal trichoid sensilla and covered elsewhere with scattered scales. Tergites 7 and 8 short, strap-like with two anterior trichoid sensilla and one lateral seta per side. Sternites 2-8 rectangular with setae more abundant mesally, a complete row of caudal setae and two basal trichoid sensilla. Female: tergites 2-7 rectangular with complete row of caudal setae, several lateral setae, two basal trichoid sensilla and covered elsewhere with scattered scales; tergite 8 divided into two longitudinal strap-like sclerites with 

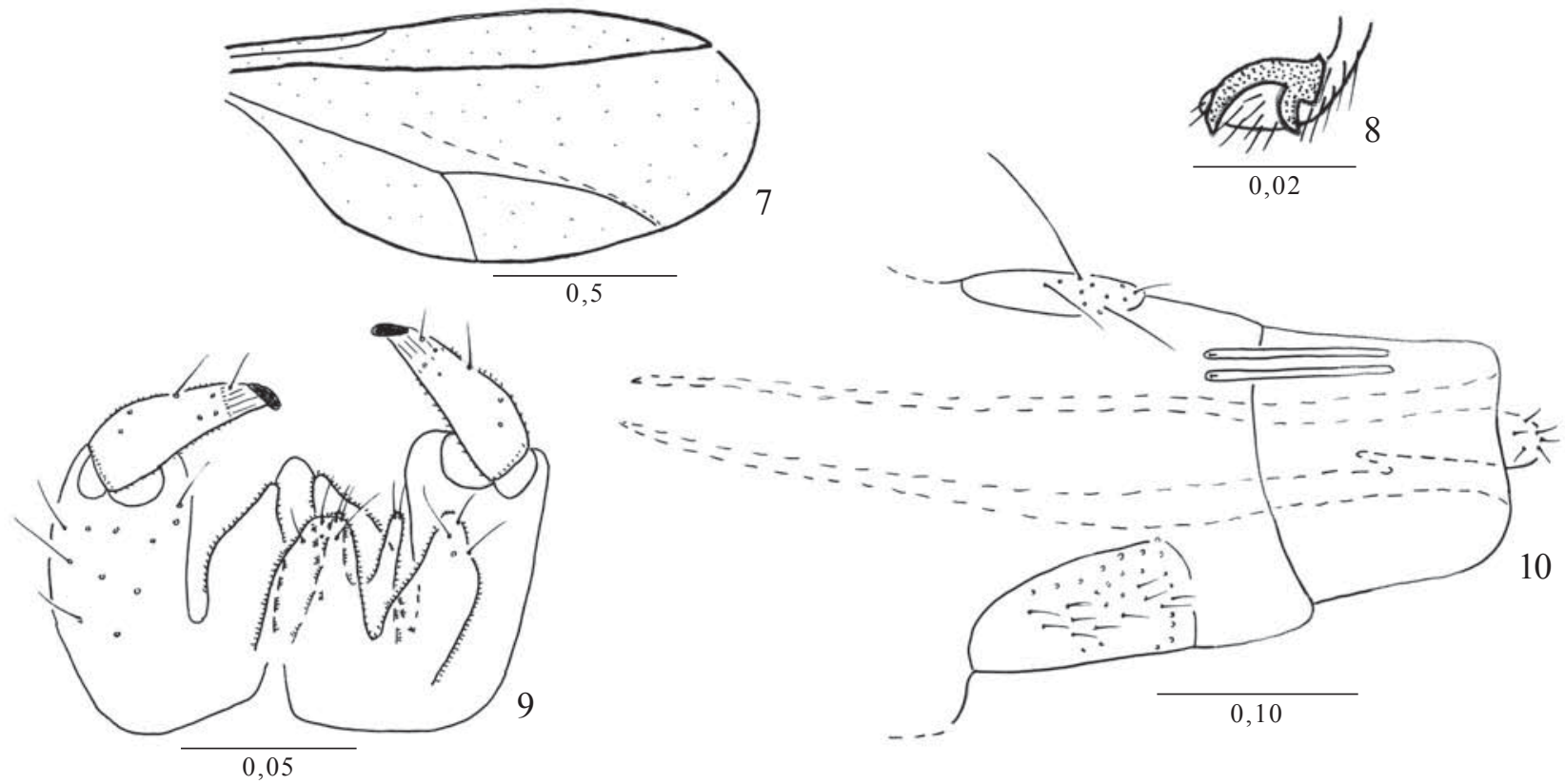

Figs. 7-10. Dasineura marginalis sp. nov.: 7, Wing, male; 8, Tarsal claw and empodium; 9, Male terminalia, dorsal view; 10, Female abdominal segments 7 to cercus, lateral view.

one seta on each side; sternites as in male. Male terminalia (Fig.9): gonocoxites wide and not splayed; gonostylus long, almost straigth and striate only subapically, cercus with lobes triangular and setose, wider than hypropoct; hypoproct bilobed, lobes narrow; hypoproct and cercus subequal in length; parameres well developed clasping aedeagus; aedeagus tapered to apex and longer than hypoproct. Ovipositor elongate-protrusible, cerci fused and setose (Fig. $10)$.

Pupa: Pale. Cephalic region (Fig. 11): antennal horn short and simple, apical seta $0.12 \mathrm{~mm}$ in length; two pairs of lower facial papilae (one setose and one bare); lateral facial papillae not visible; prothoracic spiracle digitiform with $0.06 \mathrm{~mm}$ of length. Abdominal dorsal spines absent; spinules present on abdominal tergites.

\section{Larva unkown.}

Gall (Figs. 12-13). Marginal leaf roll on Eugenia umbelliflora and on Eugenia rotundifolia.

Material. Holotype male. Brazil, Rio de Janeiro, Macaé, 04.VI.2002, P.A.L. Constantino col. (MNRJ). Paratypes: same locality, date and collector: 1 female; Arraial do Cabo, 01.X.2002, P.A.L. Constantino col., 2 males, 1 female and 1 pupal exuviae (MNRJ).

Other examined material: Brazil, Rio de Janeiro, Macaé, VIII.2003, P.A.L. Constantino col., 2 females; Maricá, IX. 2003, P.A.L. Constantino col., 2 males; same locality and collector, 02.IX.2002, 2 males and 1 female; Arraial do Cabo, VIII.2003, P.A.L. Constantino col., 1 male and 1 pupae (MNRJ).

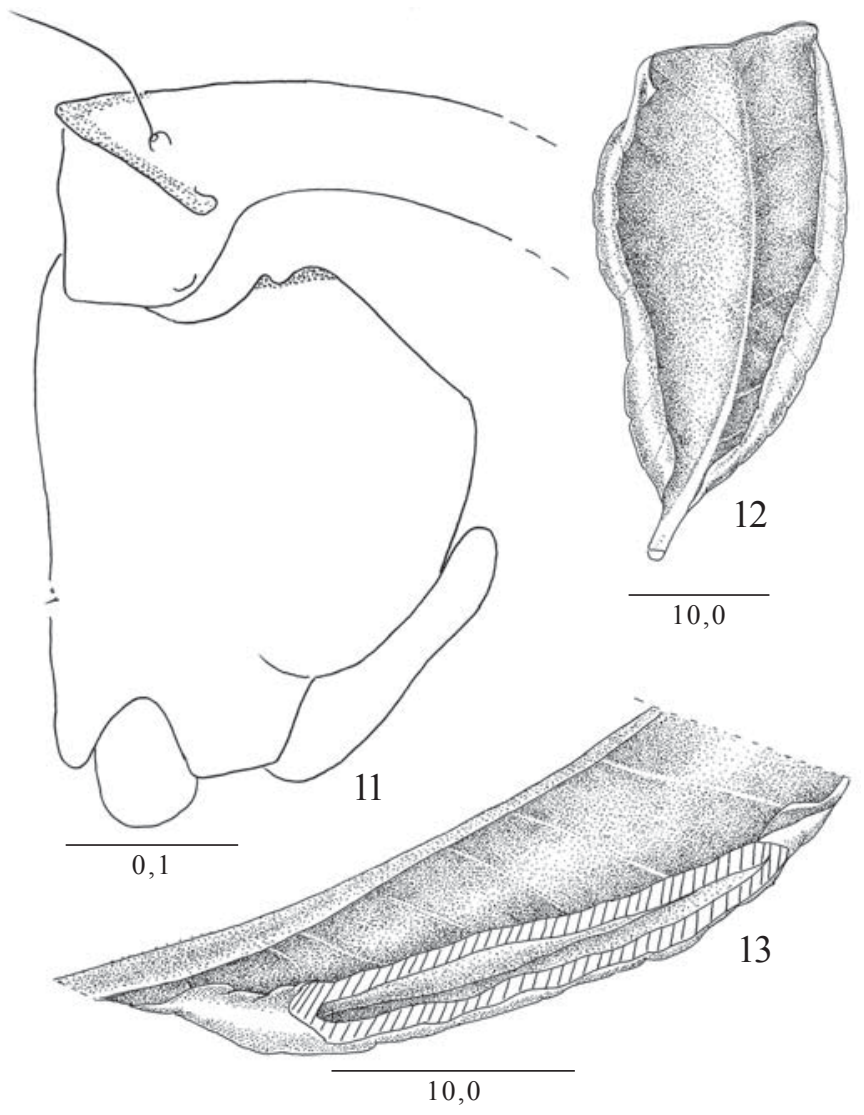

Figs. 11-13. Dasineura marginalis sp. nov.: 11, Pupa, cephalic region, frontal view; 12, Marginal leaf roll (general aspect) on Eugenia rotundifolia; 13, Marginal leaf roll (in section) on Eugenia rotundifolia. 

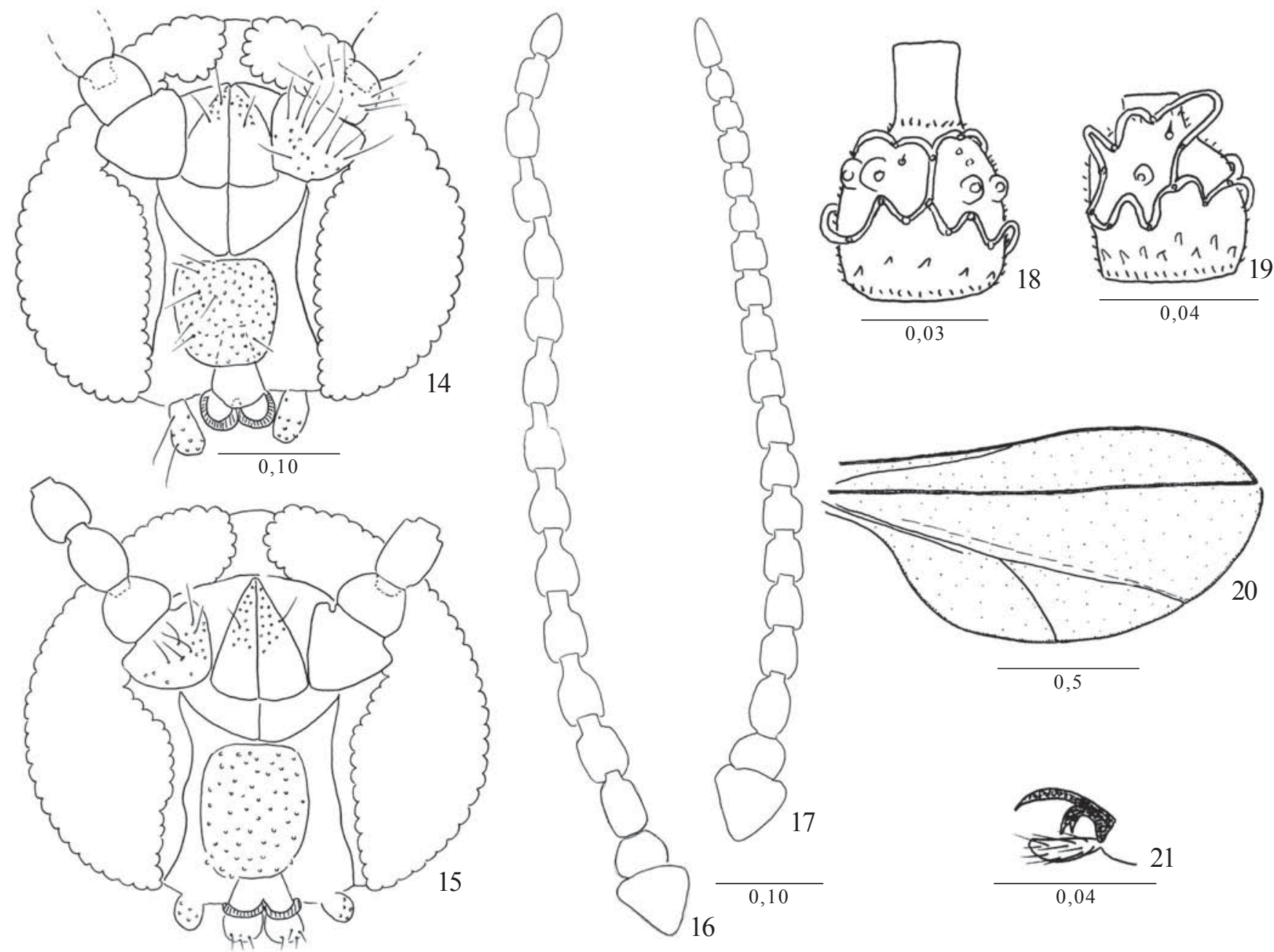

Figs. 14-21. Jorgenseniella eugeniae gen. nov, sp. nov.: 14, Male head, frontal view; 15, Female head, frontal view; 16, Male antenna; 17, Female antenna; 18, Flagellomere 5, male; 19, Flagellomere 5, female; 20, Wing, male; 21, Tarsal claw and empodium.

Etymology. The name marginalis refers to the placement of the gall at the margin of the leaf.

Remarks. This species differs from the all other known species of Dasineura mainly in the aspect of the eyes (without facets at the vertex and mesally), the high number of clypeal setae and the aspect of the gonostylus (almost straigth and striate only subapically).

Gall has a single chamber inside of that develop and pupate five to 15 larvae. The mean number of gall per leaf is about two but sometimes the number reach up to four galls. Galls are commonly found all over the year but mainly from February to April. Other Cecidomyiidae were obtained from the same kind of gall:

1. On Eugenia umbelliflora: Lestodiplosis $\mathbf{s p}$. (Macaé, RJ, 04.VI. 2002, P.A.L. Constantino col., 2 males and 1 female). Lestodiplosis Kieffer, 1894 is a cosmopolitan genus with more than one hundred described species. The larvae are predators of arthropods, including other gall midges (Gagné 1994).

2. On Eugenia rotundifolia: Lestodiplosis sp.: Maricá, RJ,
14.V.2002, P.A.L. Constantino col., 1 male; same locality and collector, VIII.2003, 2 males. This species was previously recorded in the same gall by Maia 2001. Trotteria $\mathbf{s p . : ~ M a r i c a ́ , ~}$ RJ, P.A.L. Constantino col., 2 larvae. Trotteria Kieffer, 1901 is a cosmopolitan genus with about 20 described species. The larva of all known species are inquilines in galls of other gall midges (Gagné 1994), but mostly in Asphondylia galls.

\section{Jorgenseniella gen.nov.}

Type-species: Jorgenseniella eugeniae sp. nov.

Diagnosis. Palpus one-segmented; tarsal claws toothed; female cerci separate; parameres not clasping aedeagus; larval spatula two-toothed, lateral papillae reduced in number.

Adult. Head. Occipital process absent; palpus onesegmented; 14-18 flagellomeres, circumfila anastomosing in both sexes. Thorax. Tarsal claw toothed; Rs absent; R5 straight, joining $\mathrm{C}$ just before or immediately after the wing apex; $\mathrm{M} 3$ fold present, $\mathrm{Cu}$ bifurcate. Abdomen. Ovipositor not 


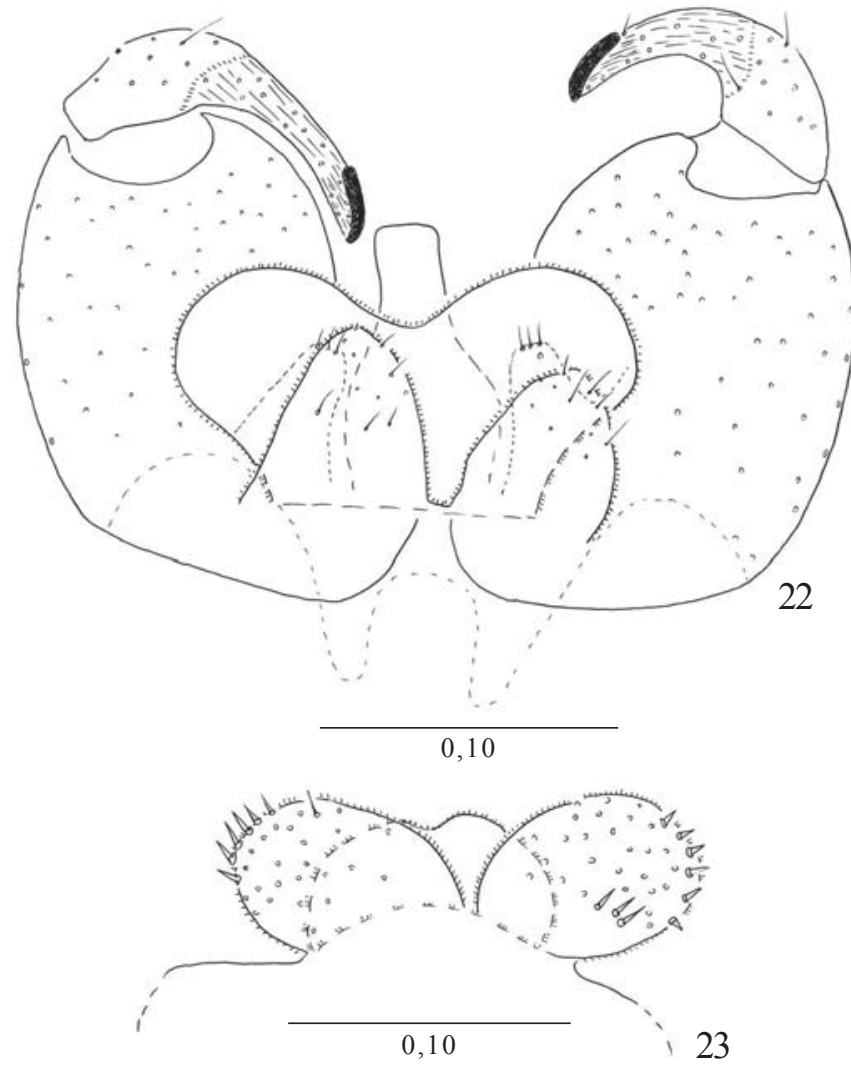

Figs. 22-23. Jorgenseniella eugeniae gen. nov, sp. nov.: 22, Male terminalia, dorsal view; 23, Ovipositor and cerci, dorsal view.

protrusible; cerci separate. Male terminalia: gonocoxite wide and not splayed; gonostylus strongly curved and clearly narrower beyond midlength to the apex; cercus bilobate; hipoproct bilobe; parameres not clasping aedeagus.

Pupae. Antennal horn simple, prothoracic spiracle rudimentary, abdomen without dorsal spines, abdominal tergites covered with diminute spinules.

Larva. Spatula two-toothed, four setose lateral papillae on each side of spatula; sternal papillae setose; ventral papillae setose; four setose terminal papillae.

Etymology. The genus is named in honor of P. Jörgensen (1870-1937), a Danish naturalist that collected insect galls in South America.

Remarks. The genus is included among the Lasiopteridi by the number of flagellomeres, Rs lacking; parameres well developed. It belongs to the tribe Oligotrophini by the irregular number of flagellomeres within species. Jorgenseniella has $\mathrm{R} 5$ shorter than the wing, joining $\mathrm{C}$ just before the wing apex or R5 as long as wing, joining $\mathrm{C}$ at or just behind the wing apex. This character causes a difficulty in couplet 18 of Gagné (1994, page 61). If one consider R5 shorter than the wing, Jorgenseniella will key to Calmonia Tavares, 1917 in couplet 27 of Gagné (1994, page 61), but the new genus does not have ovipositor protrusible neither female cerci tiny, characters present in Calmonia. But, if one consider R5 as long as wing, Jorgenseniella will key to Haplopalpus Rübsaamen, 1916, but the new genus does not have two-toothed tarsal claws, neither elaborate antennal horns (pupa). The tarsal claws have only one tooth and the pupa has simple antennal horns Furthermore, both genera differ in the number of flagellomeres: Jorgenseniella has 14 flagellomeres in male and 18 in female, while Haplopalpus has 24 flagellomeres in female (male unknown). Besides, these genera are associated with different plant families: Myrtaceae and Sapindaceae, respectively.

\section{Jorgenseniella eugeniae sp. nov.}

(Figs. 14-28)

Adult. Body length: 1.8-2.2 mm in male $(\mathrm{n}=5), 2.1-2.7 \mathrm{~mm}$ in female ( $\mathrm{n}=5)$. Head (Figs. 14-15): Eye facets circular, closely approximated except at the vertex. Antenna with 14 flagellomeres in male and 18 in female; scape obconic setose, pedicel globose and setose, flagellomere necks bare longer in male than in female. Flagellomeres cylindrical, basal ones slightly longer than the distal ones (Fig. 16-17); flagellomeres 1 and 2 not connate. Circumfila undulate in both sexes (Figs.1819). Frons triangular, sclerotized and setose; clypeus rectangular with many setae (more than 60). Labrum triangular, long-attenuate with one pair of ventral sensory setae. Hypopharynx of same shape as labrum, with long, anteriorly directed lateral setulae. Labella elongate-convex, each with several lateral setae and 7 pairs of short mesal sensoria. Palpus one- segmented, cylindrical to ovoid and setose.

Thorax. Anepimeron setose, other pleural sclerites asetose. Wing length: $1.5-1.8 \mathrm{~mm}$ in male $(\mathrm{n}=5) ; 1.5-1.7 \mathrm{~mm}$ in female $(\mathrm{n}=5)$; venation as in Figure 20. Tarsal claws bent beyond midlength and with two teeth, empodium well developed (Fig. 21).

Abdomen. Male: tergites 1-7 rectangular with complete row of caudal setae, several lateral setae, two basal trichoid sensilla and elsewhere with scattered scales. Tergite 8 not sclerotized. Sternites 1-7 rectangular with setae more abundant mesally, a complete row of caudal setae and two basal trichoid sensilla. Female: tergites and sternites as in male. Male terminalia (Fig. 22): gonocoxites wide and not splayed; gonostylus long, cerci ovoid,setose; hypoproct wide, bilobed, longer and wider than cercus; parameres triangular well separated from aedeagus, setose; aedeagus tapering from base to blunt apex.. Ovipositor short, not protrusible, cercus wide, ovoid, setose (Fig. 23). Hypoproct wide, nearly as long as cerci, without setae.

Pupa. Color: pale. Length: 1.9-2.2 mm ( $\mathrm{n}=5)$. Cephalic region (Fig. 24): antennal horn triangular, simple with $0.06-0.07 \mathrm{~mm}$ of length $(\mathrm{n}=5)$; cephalic seta not visible; facial papillae not visible; upper cephalic margin thickened laterally. Thorax: prothoracic spiracle very short $0.03 \mathrm{~mm}$ in length $(\mathrm{n}=3)$. Abdomen: dorsal spines absent, dorsal spinules present.

Larva. Body elongate cylindrical. Length: 1.6-1.9 mm (n=5). 


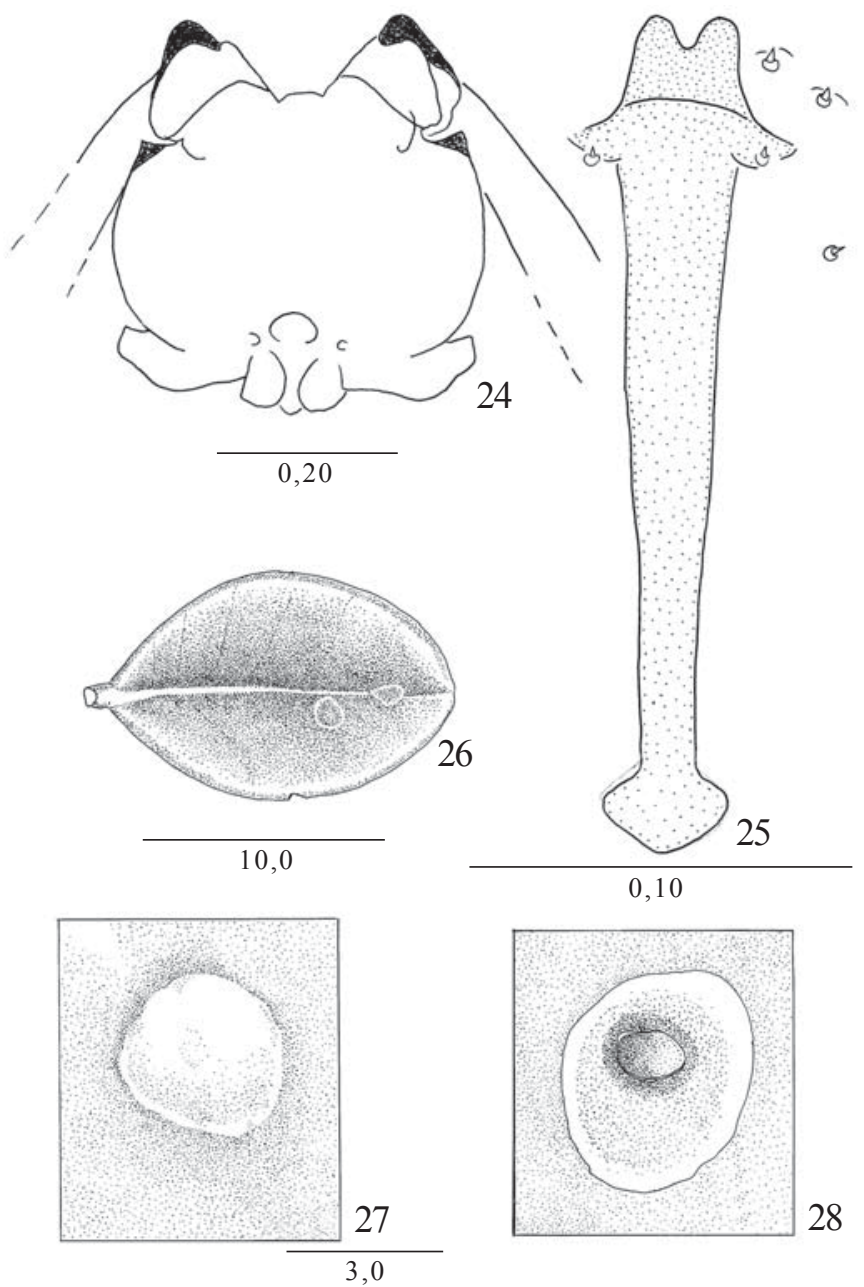

Figs. 24-28. Jorgenseniella eugeniae gen. nov, sp. nov.: 24, Pupa, cephalic region, frontal view; 25, Larva, spatula prothoracic and associated papillae; 26, Circular leaf gall (general aspect) on $E$. rotundifolia; 27, Circular leaf gall (in detail) on E. rotundifolia; 28, Circular leaf gall on E. rotundifolia (in section).

Integument rough. Spatula two-toothed with $0.23-0.26 \mathrm{~mm}$ of length (Fig. 25). Sternal papillae setose; 2 setose lateral papillae on each side of spatula; ventral papillae setose (Fig. 25). Terminal segment with four setose papillae.

Gall (Figs. 26-27). Circular leaf gall on Eugenia umbelliflora and on E. rotundifolia. The gall has a single chamber with one larvae inside that it develops and pupates. The number of galls per leaf varies up to 30 , and the average number is about 10. During its maturity and near the pupation of larvae, the gall develop a black ring around it. This gall type is one of the most abundant one in both Eugenia species occurring during all over the year, with high frequency during the period from February to April and in September.
Material. Holotype male. Brazil, Rio de Janeiro, Arraial do Cabo, 01.X.2002, P.A.L. Constantino col., (MNRJ). Paratypes: same locality, date and collector: 9 males, 11 females and 5 larvae (MNRJ); Macaé, VIII.2003, P.A.L. Constantino col., 6 pupae and 5 pupal exuviae (MNRJ).

Other examined material: Brazil, Rio de Janeiro, Arraial do Cabo, 01.X.2002, P.A.L. Constantino col., 5 males, 2 females and 4 pupal exuviae; Macaé, VIII.2003, P.A.L. Constantino col., 2 larvae (MNRJ).

Other Cecidomyiidae obtained from the same kind of gall on both Eugenia species:

Trotteria sp. (Macaé, RJ, VIII.2003, P.A.L. Constantino col., 3 larvae; : Arraial do Cabo, RJ, IX.2003, P. Constantino col, 2 larvae,.). Maricá, RJ, VII.2002, P.A.L. Constantino col., 3 larvae; same locality, VIII.2003, P.A.L. Constantino col., 4 larvae (MNRJ).

Ackowledgements. We thank Fundação de Amparo à Pesquisa do Estado do Rio de Janeiro (FAPERJ) for financial support (VCM) and scholarship (PALC), Conselho Nacional de Desenvolvimento Científico e Tecnológico $(\mathrm{CNPq})$ for scholarship and financial support (RFM) and IBAMA for license to research in the Parque Nacional da Restinga de Jurubatiba. We also are grateful to Dr. Gagné (USNM, U.S.A.) for his helpful comments.

\section{REFERENCES}

Angelo, A. C. \& V. C. Maia, 1999. Dasineura gigantea sp. n. (Diptera, Cecidomyiidae) associada com Psidium cattleianum (Myrtaceae) no Brasil. Revista Brasileira de Zoologia 16: 191-195.

Araujo, D. S. D. 2000. Análise Florística e Fitogeográfica das Restingas do Estado do Rio de Janeiro. Dissertação de Doutorado. Rio de Janeiro. Universidade Federal do Rio de Janeir, $476 \mathrm{p}$.

Gagné, R. J. 1994. The Gall Midges of the Neotropical Region. Ithaca, Cornell University Press. 356 p.

Maia, V. C., 1993a. Descrição de duas espécies novas de Cecidomyiidae (Diptera) associadas a Eugenia spp (Myrtaceae). Revista Brasileira de Entomologia 37: 717-721.

Maia, V. C. 1993b. Considerações sobre Stephomyia Tavares, 1916 (Diptera, Cecidomyiidae, Asphondyliidi) com descrição de quatro espécies novas associadas com Eugenia L. e Neomitranthes (DC.) Legr. (Myrtaceae). Revista Brasileira de Zoologia 10: 521530.

Maia, V. C., 1995. Três espécies novas de Dasineura Rondani, 1840 (Diptera, Cecidomyiidae) associadas a Myrtaceae na Restinga da Barra de Maricá (RJ). Revista Brasileira de Zoologia 12: 10011008.

Maia, V. C. 2001a. New genera and species of gall midges (Diptera, Cecidomyiidae) from three restingas of Rio de Janeiro State, Brazil. Revista Brasileira de Zoologia 18: 1-32.

Maia, V. C. 2001b. The gall midges (Diptera: Cecidomyyiidae) from three restingas of Rio de Janeiro State, Brazil. Revista Brasileira de Zoologia 18: 583-629.

Monteiro R. F.; F. F. F. Ferraz; V. C. Maia \& M. A. Azevedo. 1994. Galhas entomógenas em restingas: uma abordagem preliminar. Anais da Academia de Ciências de São Paulo - Aciesp 3: 210-220.

Monteiro R. F.; R. A. Oda; K. L. Narahara \& P. A. L. Constantino. 2004. Galhas: diversidade, especificidade e distribuição. In: C. F. D. Rocha; F. A. Esteves \& F. R. Scarano (Orgs). Pesquisas de longa Duração na Restinga de Jurubatiba: Ecologia, História Natural e Conservação. RiMa Editora, São Carlos. 